\title{
Gyldigheten av troskapsavtale mellom samboere
}

\section{Innledning}

Temaet for denne artikkelen er adgangen som finnes i norsk rett for samboere til å inngå avtaler om troskap med $\varnothing$ konomiske sanksjoner ved vilkårsbrudd. Tematikken ble nylig belyst i en lagmannsrettsdom: LH-2017-129425. Dommen gjelder gyldigheten av en avtale om troskap mellom samboere: Etter at den ene samboeren hadde vært utro, inngikk partene en avtale om at bolig og bil som partene eide sammen, i sin helhet skulle tilfalle den andre dersom en av dem var utro. Etter at avtalen ble inngått, var mannen utro på ny. De rettslige spørsmålene som har nærmere interesse, var hvorvidt avtalen stred mot kravet om ærbarhet i avtaleforhold jf. NL 5-1-2 og videre hvorvidt avtalen var urimelig jf. avtaleloven $§ 36$. Lagmannsretten kom frem til at kontrakten verken stred mot ærbarhet eller var urimelig. Resultatet ble at avtalen skulle oppfylles.

Ved første øyekast kan nok slike avtalevilkår om troskap i samlivet mellom samboere som ved brudd får en $\varnothing$ konomisk sanksjon, fremstå som en blanding av «inkommensurable størrelser» som det på generelt grunnlag vil være grunn til å møte med skepsis, når avtalens rimelighet skal vurderes. I norsk økonomisk familierett har man stort sett forlatt en tankegang om at skyld eller umoral skal få økonomiske konsekvenser i oppgjør mellom ektefeller. ${ }^{1}$ Noen aspekter ved denne konkrete saken illustrerer riktignok at det i enkelte tilfeller kan være et aktuelt og rimelig behov for å inngå slike avtaler mellom samboere. I kjølevannet av dommen kan det spørres om hvilke generelle hensyn som reiser seg for avtaleadgang og urimelighetssensur av slike avtaler og hvordan de passer inn med den nøkterne rettskulturen som norsk familierett er preget av og som i liten grad knytter økonomiske konsekvenser til handlinger som kan anses som umoralske og dårlige i et parforhold.

Et annet moment som det er verdt å se nærmere på, er at en slike avtaleadgang antagelig ville være stengt for ektefeller, ettersom den ville stride mot mulighetene for å lage oppgjørsavtaler i forkant av samlivsbruddet jf. ekteskapsloven kapittel 9. ${ }^{2}$ En kan spørre seg om hvorvidt denne forskjellen i adgangen til å regulere oppgjør i forkant av brudd er fornuftig tatt i betraktning de hensyn som reiser seg for de to situasjonene.

\footnotetext{
${ }^{1}$ Se Lødrup, P. og Sverdrup, T. 2016: Familieretten. 8. utgave. Oslo, s. 77-78; Sverdrup, T. 1997: Stiftelse av sameie i ekteskap og ugift samliv. Oslo: Universitetsforlaget, s. 312; Strandbakken, A. 2018: Økonomisk familierett. Bergen: Fagbokforlaget, s. 19-20.

${ }^{2}$ Lov 4. juli 1991 nr. 47 om ekteskap (heretter forkortet til ekteskapsloven eller el.).
} 


\section{Sakens faktum}

Dommen gjelder gyldigheten av en avtale om troskap mellom samboere. Avtalen var som nevnt foranlediget av at den ene samboeren hadde vært utro, hvorpå partene inngikk en avtale om at bolig og bil som de eide sammen, i sin helhet skulle tilfalle den andre dersom en av dem var utro på ny. Avtalen la altså de samme forpliktelsene på begge parter og ville således også ha rammet kvinnen dersom det var hun som hadde vært utro. Ektefellene eide hver en halvpart av boligen som ved avtaleinngåelsen var verdt fire millioner kroner. De hadde skutt inn1, 2 millioner kroner hver og resten (kr 800 000) var finansiert gjennom et lån som de heftet for med en halvpart hver. Bilen kjøpte de sammen for kr 400 000, hvor hun betalte kr 300000 og han betalte kr 100000.

Ved avtaleinngåelsen hadde partene ett barn sammen. Mannen var økonomisk sett den som sto sterkest av dem, han hadde foruten sin andel i boligen og bilen som var omfattet av avtalen, en ligningsformue på ca. 11, 5 millioner kroner samt en ytterligere bolig som var nedbetalt. Kvinnen hadde ingen formue utover verdiene som var omfattet av avtalen.

3. Nærmere om urimelighetsvurderingen i dommen

\subsection{Frbarhetsvurderingen}

Mannen hevdet at avtalen stred mot ærbarhet, jf. NL 5-1-2. Ærbarhetsvurderingen etter NL 51-2 retter seg mot grovere tilfeller av umoralske avtaler; avtaleforhold som strider mot grunnleggende moraloppfatninger i samfunnet. ${ }^{3}$ I dommen vises det til avtaler som «pålegger en part vesentlige og urimelige begrensninger $i$ den personlige frihet og dersom avtalen pålegger en part å gi avkall på legemlig integritet.» ${ }^{4}$ Innholdet i bestemmelsen vil riktignok fanges opp av avtaleloven $\S 36$, og vil nok kun være aktuell der det er et særlig behov for å markere en avtales umoralske karakter. ${ }^{5}$ Til dette kan det bemerkes at det er noe fremmed ved en slik avtale siden den fører til store $\varnothing$ konomiske konsekvenser for den som foretar seg noe som må sies å være av personlig karakter. Likevel fant retten at den aktuelle avtalen klart var utenfor hva som rammes av som stridende mot ærbarhet i NL 5-1-2. Dette ble begrunnet med at avtalen hadde et aktverdig formål, nemlig å sikre at samlivet kunne fortsette. Videre fant domstolen det faktum at mannen ikke ville ha blitt rammet av avtalen dersom han først hadde brutt samlivet og deretter innledet et forhold til en annen, gjorde at avtalen ikke virket

\footnotetext{
${ }^{3}$ Woxholth, G. 2011, Avtalerett. Oslo: Gyldendal akademisk, s. 280-281; Hov, J. Avtaleslutning og ugyldighet Kontraktsrett I, Papinian, s. 207; Giertsen, J. 2006, Avtaler, Universitetsforlaget, s. 188.

${ }^{4}$ Dommen s. 5

${ }^{5}$ Woxholth, G. 2011: Avtalerett. Oslo: Gyldendal akademisk, s. 280.
} 
urimelig inngripende $\mathrm{i}$ hans frihet eller integritet. Disse momentene blir også av relevans under den generelle vurderingen av avtaleloven $\S 36$, se neste punkt.

\subsection{Urimelighetsvurderingen for $\emptyset v$ rig jf. avtaleloven $\S 36$}

Mannen hevdet videre at avtalen var i strid med avtaleloven $\S 36$. Generelt er terskelen for å sensurere avtaler jf. avtaleloven $\S 36$ på grunn av urimelighet høy; også når det gjelder avtaler mellom samboere og mellom ektefeller. ${ }^{6}$

Mannen anførte at forhold ved avtaleinngåelsen medvirket til å gjøre avtalen urimelig. Han hevdet at han at han ble presset til å inngå avtalen og at han ikke hadde tilstrekkelig tid til å tenke seg om før avtaleinngåelsen. Dette ble han ikke hørt med. Retten la til grunn at han hadde hatt flere dager til å vurdere avtalen, og at han forøvrig ikke var i en situasjon da som gjorde at avtalen ble urimelig.

Den negative effekten av å blande sammen det $\varnothing$ konomiske og det personlige vil variere med konteksten avtalen er laget i. Avtaler hvor samboerne blander sammen det personlige og det $\emptyset$ konomiske uten at det foreligger noen grunn til å tro at den ene eller andre skal oppføre seg på en måte som kan true samlivet, er det grunn til å møte med en viss skepsis fra rettssystemet. I den situasjonen som dommen er et eksempel på, stiller dette seg annerledes: Avtalen var foranlediget av at mannen hadde vært utro. Kvinnen fant utroskapen uakseptabel, og avtalen ble inngått som et ledd i en ny start på forholdet. Det personlige og det økonomiske i det faktiske livet til samboerne var dermed allerede sammenblandet. Avtalen som reflekterer denne sammenblandede situasjonen mellom partene ivaretar legitime hensyn som vanskelig kunne sikres på alternative måter.

Ett slikt hensyn er behovet for økonomisk sikkerhet ved et brudd for den ene eller begge parter. Kvinnen som sto svakest $\varnothing$ konomisk av partene, ville kan hende ha begrenset mulighet til å bryte ut av samlivet dersom hun ikke var sikret gjennom avtalen. Hun hadde, sammen med mannen, ansvar for et barn som bare var tre måneder da utroskapen som foranlediget avtalen ble oppdaget. Dette ansvaret tilsier også et behov for å økonomisk sikkerhet ved et eventuelt brudd.

\footnotetext{
${ }^{6}$ Dette kommer for eksempel fram i Rt. 2011 s. 1168 som gjaldt gyldigheten av en $\varnothing$ konomisk oppgjørsavtale mellom samboere. Se Bull, K.S. 1993, Avtaler mellom ektefeller, Tano, s. 273-274.
} 
Avtalen ville videre gi henne en sikkerhet for at samlivet fortsatte på en måte som hun kunne godta, altså at de begge var tro mot hverandre. På denne måten fremtrer avtalen som legitim sett i lys av den situasjonen partene var i da avtalen ble inngått.

Dette st $\varnothing t t e s$ av det ikke er lett å se for seg noen mindre inngripende måte å regulere forholdet ut fra mannens perspektiv. Et alternativ, som kunne ha sikret de samme hensynene som avtalen skulle ivareta, ville være om han overførte verdiene til henne der og da, men dette ville gi han mindre sikkerhet for at forholdet ville vare, og ville også vært mer byrdefullt for ham i og med at han da ikke ville kunne ha vernet seg mot de økonomiske sanksjonene ved å bryte ut av samlivet før han inngikk et forhold til en annen person.

Når det gjelder vurderingen av styrkeforholdet mellom partene, vil det være fornuftig å skille mellom situasjonen i samboerforholdet generelt, situasjonen rundt avtaleinngåelsen og betydningen av resultatet av avtalen for hver av dem. En slik fremgangsmåte er for $\varnothing v$ vig helt alminnelig når det gjelder rimelighetssensur av avtaler og i tråd med systematikken i avtaleloven § 36. Et interessant trekk ved saksforholdet i dommen er i så måte at partene hadde forskjellige styrker og svakheter i forhold til hverandre. Kvinnen var den som var $\emptyset$ konomisk svakest og hun var også den som var forulempet gjennom at samboeren var utro. Samtidig ga utroskapen henne et moralsk overtak. Mannen fremstår som den svake parten i selve avtaleforholdet. Det at han hadde vært utro, gjorde at han hadde mindre mulighet til å påvirke avtalens innhold. Dessuten hadde kvinnen et overtak ved at hun fikk hjelp av sin far som var lagdommer og som med juridisk kunnskap kunne hjelpe henne å formulere selve avtalen. Dette må sies å gi henne en fordel ved avtaleinngåelsen.

Ser man det fra den som har vært utro sin side, kan det å bli møtt med et slikt krav om avtale nok føles som vanskelig å imøtegå. Den følelsesmessige siden av saken er vanskelig å måle i ettertid. Men om man sier nei, sier man kanskje nei til å fortsette forholdet. Kanskje føler man seg heldig som er blitt gitt en ny sjanse. Dette vil kanskje gjøre det vanskelig å nekte å inngå en avtale som gir økonomiske følger om man skulle være utro igjen. På denne bakgrunn er det viktig å vurdere den økonomiske situasjonen som samboerne sto i da avtalen ble inngått og hvilket resultat den vil føre til for hver av dem.

Avtalen innebar en ensidig overføring fra mannen til kvinnen på 1, 5 millioner kroner, men sett i lys av hans økonomi for $\varnothing v$ rig, ble ikke dette resultatet av avtalen ansett for å være urimelig. Mannen var i en god økonomisk situasjon, med en ligningsformue på ca. 11, 5 millioner kroner samt en nedbetalt bolig ved siden av de verdier som var omfattet av avtalen. 
Det må kunne sies at det økonomiske resultatet av avtalen alt $\mathrm{i}$ alt er et rimelig og normalt resultat av en deling av et samboerpars eiendeler etter et brudd. Hun satt igjen med verdier tilsvarende den gjeldfrie delen av boligen og bilen, som ved avtaleinngåelsen var verdt ca. 2,8 millioner kroner. Det ville stilt seg annerledes dersom det som skulle overføres var brorparten av det mannen eide, som nok ville føre til en økonomisk vanskelig situasjon etter samlivsbruddet. Dessuten er det et poeng at avtaler som har hatt et mer inngripende $\emptyset$ konomisk resultat for den ene ektefellen, i rettspraksis har vært ansett for å gå klar av urimelighetsreglene mellom ektefeller. Eksempler på dette finner vi i to høyesterettsdommer fra slutten av 60-tallet (Rt. 1967 s. 973 og Rt. 1969 s. 901). Her var mannen i begge saker alkoholisert og inngikk avtale med ektefellen om at ekteskapet skulle fortsette mot at han sluttet å drikke. Samtidig ble verdier som ektemannen eide overført til kvinnens eneeie og særeie ble opprettet for disse verdiene. I begge sakene kom Høyesterett til at avtalen var gyldig og ikke i strid med dagjeldende krav til rimelighet i avtaleforhold. Det ble lagt avgjørende vekt på hensynet til kvinnene. Kvinnens behov i samlivet med ektemanen, som avtalene skulle sikre, ble ansett for å være avgjørende for vurderingen av avtalenes rimelighet.

Det kan vel også tenkes at mannens drikkfeldighet, som hadde tappet formuen i boet, i realiteten ble ansett for å utgjøre ektemannens «del», slik at det som var igjen, ut fra rimelighet kunne tilfalle kvinnene. Dommene er gamle og bærer til en viss grad preg av at saksforholdene i disse sakene var tidstypiske på den måten at kvinnene var avhengige av ektefellene for forsørgelse. Dette forhindrer ikke dommene fra å fortsatt ha relevans ${ }^{7}$. Rettskildene taler i retning av at det skal mye til for at en avtale der verdier overføres fra den ene til den andre skal settes til side, så lenge begge parter har gitt et informert samtykke til avtalen. Dette henger sammen med at terskelen for å sensurere avtaler på grunn av urimelighet generelt er høy; også når det gjelder avtaler mellom samboere og mellom ektefeller. ${ }^{8}$

Det prinsipielle ved at det innføres en avtalemessig sanksjon for oppførsel som ikke er ulovlig, og som det eksplisitt er tatt stilling til at ikke skal ha betydning for skilsmisse eller deling mellom ektefeller, kan ha en betydning for rimelighetsvurderingen. Igjen må vi se

\footnotetext{
7 Dommene er omtalt av Kirsti Strøm Bull i hennes bok Avtaler mellom ektefeller (1993) punkt 4.3.1. Etter hennes oppfatning etterlater de et inntrykk av at $\mathrm{H} \varnothing$ yesterett er «meget tilbakeholden med å kjenne en avtale mellom ektefeller ugyldig», s. 230

${ }^{8}$ Dette kommer for eksempel fram i Rt. 2011 s. 1168 som gjaldt gyldigheten av en økonomisk oppgjørsavtale mellom samboere. Se også Rt. 1970 s. 561 som gjaldt gyldigheten av en ektepakt og som trekker i samme retning som de ovennevnte dommene.
} 
nærmere på de hensynene denne lovgivningen er basert på. Et hensyn er at man skal være fri til å forlate et ekteskap; man skal ikke bindes til et ekteskap fordi en skilsmisse ville føre til at man får en vanskelig økonomisk situasjon. Avtalen i den gjeldende saken var imidlertid slik at mannen når som helst kunne forlate samboerskapet for så å innlede forhold til en ny, uten at dette ville ha noen $\varnothing$ konomisk konsekvens for han.

4. Sammenligning med avtaleadgangen mellom ektefeller

Avtalen har noen likhetstrekk med en ekteskapsavtale ved at den gir økonomiske følger i delingen etter et brudd mellom partene; noe som ikke følger av norsk rett når samboere går fra hverandre. I avtalen er dog troskap helt eksplisitt tatt inn som et vilkår for at den økonomiske sanksjonen ikke skal inntreffe, mens troskap mellom ektefellene normalt ikke får noen $\emptyset$ konomiske følger ved ekteskapsoppløsning.

Det er usikkert hvorvidt en slik avtale i det hele tatt kunne vært inngått mellom ektefeller. En forhåndsavtale om overgang av midler fra den ene ektefellen til den andre vil være mulig så lenge kravene om ektepakt er fulgt, jf. ekteskapsloven $\S 50$ jf. $§ 54$. Men i den grad den ville anses å være en forhåndsavtale om det økonomiske oppgjøret etter endt ekteskap, måtte den i så fall være i samsvar med et av de alternativene som er listet opp i ekteskapsloven kapittel 9, som utgjør en ramme for gyldigheten av slike avtaler mellom ektefeller.

Dersom det eksplisitt er forutsatt $i$ avtalen at utroskapen vil ende med et samlivsbrudd, vil vilkårene i ekteskapsloven om forhåndsavtaler være brutt og det vil ikke være adgang til å inngå en slik avtale mellom ektefeller. Hvorvidt det skal være avgjørende om formuesoverføringen uttrykkelig er gjort avhengig av ekteskapets opphør/samlivsbrudd eller om skal det være nok for ugyldighet at det i realiteten bare vil være da at vilkåret om formuesoverføring er aktuelt, har vært drøftet i teorien. Dette er et generelt gyldighetsspørsmål som ikke bare oppstår ved vilkår om utroskap. Tone Sverdrups synspunkt er at avtalen i sin alminnelighet går klar av begrensingene i kapittel 9 så sant formuesoverføringen ikke uttrykkelig er knyttet til ekteskapets opphør, ettersom det ofte er vanskelig å oppnå nevneverdig økonomisk realitet under selve samlivet og det heller ikke er 
behov for å demme opp for omgåelser slik som i arveretten. ${ }^{9}$ Kirsti Strøm Bull har lignende synspunkter. ${ }^{10}$

Et annet poeng som fremkommer ved å sammenligne med den rettslige situasjonen for ektefeller, er hensynene bak at avtaleadgangen om formuesordningen er uttømmende regulert i ekteskapsloven. Dette er blant annet begrunnet med behovet for å skape forutberegnelighet for ektefellene, og for at de ikke skal ha adgang til å inngå avtaler med virkning langt inn i fremtiden og som de ikke vil kunne forutse konsekvensene av. Dette hensynet må også sies å gjøre seg gjeldende for samboere i og med at avtaler om et oppgjør dem imellom også vil kunne få konsekvenser langt inn i fremtiden. Dette vil derfor være et relevant moment i den generelle urimelighetsvurderingen. Riktignok må dette ses i lys av at samboere i større grad har behov for å inngå slike avtaler seg imellom enn ektefeller, nettopp fordi det ikke er noen lov som regulerer oppgjøret mellom samboere ved et samlivsbrudd.

Ektefeller vil riktignok kunne inngå avtaler under ekteskapet om at midlene overføres fra den ene til den andre og gjøres til dennes særeie, så lenge reglene om gaver og ektepakt er fulgt. Her kan det tenkes avtaler nettopp som reaksjon på utroskap, for å sikre samlivet og gi en $\emptyset$ konomisk sikkerhet for den andre ektefellen. En slik situasjon vil være en større byrde for den som avgir midler enn det ville ha vært for mannen i vår sak, ettersom hun/han ikke vil kunne unngå den økonomiske konsekvensen av avtalen ved et eventuelt brudd. På samme måte som ved situasjonen i dommen, kan man tenke seg at det vil være et legitimt behov hos den andre å sikre seg økonomisk ved et brudd dersom hun/han på grunn av den andres utroskap frykter for at denne vil være utro igjen, og derfor frykter for at det vil bli et brudd mellom dem.

Rettspraksis gir inntrykk av at det skal svært mye til for å sette en avtale mellom ektefeller til side - enten det dreier seg om formuesordningen, gaver eller oppgjørsavtaler. ${ }^{11}$ De nevnte høyesterettsdommene som gjaldt overføring av midler fra en ektefelle som misbrukte alkohol, kan sees som eksempler på dette. ${ }^{12}$ Dommene gir inntrykk av at ektefellenes situasjon ikke holdes adskilt i rimelighetsvurderingen, men at Høyesterett legger stor vekt på det felleskap som har vært mellom partene, slik at der ektepakten har vært et ledd i å berge ekteskapet, skal

\footnotetext{
${ }^{9}$ Sverdrup, T. 2016, Ugyldighet i famileretten: Grensen mellom rene formuerettslige avtaler og forhåndsavtaler ved oppgjøret. I Erling Hjelmeng (red.), Ugyldighet i privatretten: minnebok for Viggo Hagstrøm, Fagbokforlaget 2016, s. 469-470.

10 Bull, K. S. 1993: Avtaler mellom ektefeller. Oslo: Tano s. 51

${ }^{11}$ Bull, K. S. 1993: Avtaler mellom ektefeller. Oslo: Tano, s. 273-274.

12 En annen dom som trekker i denne retningen er Rt. 1990 s. 1099
} 
det mye til for at den kjennes ugyldig. ${ }^{13}$ Jeg vurderer ikke nærmere urimelighetsnormen i et slikt tilfelle.

\section{Avslutning}

Ved at man lever livene sine sammen, skjer det ofte en reell sammenblanding av økonomiske og personlige faktorer. Dette gjør at det oppstår noen utfordringer for hvordan det $\varnothing$ konomiske skal reguleres. Det å blande det $\varnothing$ konomiske med det følelsesmessige og personlige fremstår som uheldig på ulike måter, men denne aktuelle saken viser at det likevel kan være legitime hensyn som gjør seg gjeldende for å inngå slike avtaler. På et generelt nivå illustrerer saken at det bør være en skepsis mot slike avtaler dersom de for eksempel er inngått i starten av et samboerskap, og det må innenfor rammen av avtaleloven $\S 36$ ses i sammenheng med situasjonen partene for øvrig står i.

Videre reiser det seg enkelte spørsmål om avtaleadgangen mellom ektefeller er basert på noen hensyn som burde tillegges større vekt $\mathrm{i}$ en rimelighetsvurdering av gyldigheten av $\emptyset$ konomiske avtaler mellom samboere. Regelen om at man ikke skal kunne binde seg til en oppgjørsavtale som ikke ligger innenfor rammen av ekteskapsloven kapittel $9 \mathrm{i}$ forkant av et brudd er blant annet basert på hensyn om at ektefellene ikke vil overskue konsekvensene av avtalen langt inn i framtiden. Dette kan være et hensyn som også bør tas med i rimelighetsvurderingen når avtalen er inngått mellom samboere. Riktignok vil det forhold at avtalen kun gjennomføres dersom vilkårene blir brutt, slik det var i vår sak, gjøre avtalen mindre inngripende enn det vil være for avtaler som typisk vil inngås mellom ektefeller. Avtaler som har som formål å sikre den ene ektefelle ved et nytt tilfelle av utroskap og samlivsbrudd vil ofte innebære at eiendom overføres og gjøres til særeie for denne parten.

\footnotetext{
${ }^{13}$ Bull, K. S. 1993: Avtaler mellom ektefeller. Oslo: Tano, s. 274.
} 